\title{
Explaining Durable Diversity in International Systems: State, Company, and Empire in the Indian Ocean
}

\author{
Andrew Phillips, University of Queensland, Australia \\ J.C. Sharman, Griffith University, Australia
}

\section{Acknowledgements}

The authors are grateful for the invaluable feedback provided in response to earlier drafts of this work by Amitav Acharya, Charles Butcher, Alex Cooley, Luke Glanville, Ryan Griffiths, Seb Kaempf, Peter Katzenstein, Manjeet Pardesi, Chris Reus-Smit, Hendrik Spruyt, Shogo Suzuki, William Thompson, Wes Widmaier, three anonymous reviewers and the editors of ISQ. The authors would also like to gratefully acknowledge the financial support of Australian Research Council Grants DE130100644 and FT120100485. 


\begin{abstract}
International Relations theories generally hold that increased interaction between units in an international system produces convergence in unit forms through military competition, institutional emulation, or normative socialization. Conversely, this article presents a constructivist explanation of how diverse international systems can endure despite increasing interaction. The early modern Indian Ocean international system hosted a variety of statist, corporate, and imperial polities. Diversity endured for three reasons. First, differing maritime and land-oriented preferences held by powerful foreign and local actors created the potential for coexistence between unlike polities. Second, durable polity diversity was facilitated by congruent European and Asian ideas of heteronomy. Third, enmeshment was realized through strategies of localization. Convergence on common polity forms failed to occur despite the presence of a statist model throughout this period. Subsequently, this order was succeeded not by like units under anarchy, but by a re-configured form of diversity under colonial empires. Greater attention to past diverse systems accords with recent calls to study history to better understand contemporary instances of international hierarchy and unbundled and shared sovereignty.
\end{abstract}


How can we explain the growth and persistence of diverse, unlike polities within international systems? Drawing on stylized understandings of the European experience, many realists, rationalists, and constructivists portray the early modern period as defined by a master process of homogenization, whereby diverse polity forms converged on the sovereign state model. Increased interaction supposedly drove this homogenization, although each school differs on the relative importance of military and economic competition and normative socialization in propelling this process. Against this narrative, increased military, economic and cultural interaction failed to promote convergence in the Indian Ocean region. In keeping with Waltz's dictum that "international political structures are defined in terms of the primary units of the era, be they city-states, empires or nations” (Waltz 1979: 91), the diversity of this system was constituted by state, company, and empire. Evidence is drawn from the history of the Portuguese Estado da India (State of India), the Dutch and English East India Companies, and the Mughal Empire.

We argue that three related factors explain durable diversity in the Indian Ocean international system. First, because of different and complementary culturally derived preferences, Europeans and powerful local polities were not competing for the same stakes. Specifically, the Europeans were focused on the control of maritime areas, networks and trade as the main prize of military struggle, while they were largely indifferent to ruling large land areas or populations. In contrast, local actors like the Mughal Empire wanted the opposite: control of land and people, while they did not view the seas as something to be fought over or controlled. As a result, the purportedly universal situation of zero-sum security competition did not eventuate. 
If differing cultural orientations toward trade and conquest enabled the entry of new polity forms into the region, it was culturally distinct but structurally similar conceptions of rightful authority that facilitated the subsequent stability of the diverse regional order. In particular, prior congruent beliefs among locals and Europeans about the legitimacy of sharing and splicing authority among different polities were crucial (in contrast to contemporary standards of strictly-bounded states holding untrammeled authority within their own borders). We use John Ruggie’s term "heteronomy” to describe this overlapping patchwork of authority relations (Ruggie 1983).

Finally, actors' agency was central, as Europeans adapted themselves to fit local beliefs and practices. In line with Amitav Acharya (2004), we define these practices as a process of "localization.” Rather than a uniform commitment to deep constitutional values, these were improvised accommodations worked out in the context of cultural, diplomatic and commercial exchange. Thus different and complementary preferences, congruent traditions of heteronomy, and agent-centered practices of localization jointly produced a system of territorially nonexclusive, diverse polities.

Our argument proceeds in five sections. Section one first establishes the gap in the literature we seek to fill, identifying and critiquing realist, rationalist and constructivist versions of the interaction/convergence thesis. It then recovers implicit theories of diversity within these theoretical traditions, paying particular attention to constructivism. In particular, the common tendency in these implicit theories to relax the assumption of strictly-bounded units provides an important segue into our thesis. 
In section two, we argue that polity diversity may persist when polities possess different but complementary preferences over trade and conquest; when they share congruent traditions of heteronomy allowing the intermingling of authority structures; and when agents are willing to tolerate and accommodate differences through practices of localization. Rather than these mechanisms favoring like units with definite boundaries, as in Europe, in the Indian Ocean this dynamic consolidated the interweaving of heteronomous, overlapping polities. This finding underscores Ruggie's emphasis on the importance of principle of separation between units in constituting international systems $(1983,1998)$.

Section three introduces the early modern Indian Ocean as an example of a durably diverse international system, and tests our argument both against the evidence and alternative explanations. The most important actors were the statist Portuguese Estado da India, the Dutch and English Company sovereigns, and the Mughal Empire. The Estado da India was organized on statist lines, with a strict hierarchy of centralized command running from King to Viceroy to local agents. The Companies had shareholders and hard budgets, but also enjoyed key sovereign powers and possessed their own armies and navies. Finally, the Mughal polity was a classic empire, structured by heterogeneous contracting with intermediary rulers, and gradations of authority radiating outwards from the ruler to the empire's frontiers. These polities were distinct from one another, but interpenetrated over the succeeding three centuries.

Section four explains how diversity endured once Europeans attempted to upend the earlier equilibrium by pursuing large-scale territorial conquest, embracing territorially exclusive conceptions of authority, and ditching localization for attempted standardization after 1750 . Unlike Europe, which evolved from medieval heteronomy to sovereign anarchy, the Indian Ocean did not belatedly emulate this trajectory from the mid-eighteenth century. Instead, the 
lock-in effects of earlier heteronomy constrained European attempts at modernization. The resulting colonial empires overlaid rather than effaced earlier diversity, producing a reconfigured heteronomous hierarchy that persisted into the mid-twentieth century.

The final section extracts more general implications from our argument. While cautious not to exaggerate its reach, we maintain that this framework can aid in understanding diverse historical international systems beyond the Indian Ocean, including steppe Asia and colonial North America. A greater understanding of diverse historical international systems may also help to understand the resurgent heterogeneity now reshaping today’s global international system.

There are limitations to the conclusions that can be drawn from the study of any one region. But judging from the long history of IR scholarship generalizing on the basis of European experience, analyzing another region may provide important theoretical insights. To the extent that IR is a social science seeking generalizable explanations, and not a kind of European area studies, it is appropriate to test explanations developed from one region against new evidence from another. Pioneering efforts to broaden IR's geographical horizons to East Asia have strongly suggested the discipline should rethink its reflexive privileging of sovereign anarchy as the universal norm in international politics (e.g., Hui 2005; Kang 2010). Our argument below further corroborates this conviction.

\section{Three Mechanisms of Convergence: Military Darwinism, Economic Competition, and Normative Socialization}


We live today in an unusually homogenous era. Historically, most international systems contained diverse polity forms, from city-states through to city leagues, armed trading companies, confederacies, and empires. The master process of homogenization, whereby diverse units were winnowed out in favor of the sovereign state, is one of the field's defining problems. How do IR scholars conventionally explain this transformation from difference to sameness?

Realism posits that military competition and elimination constitute the greatest stimulus for convergence among polities. Innovations that enhance polities’ survival prospects are likely to spread rapidly, encouraging a more homogenous international system over time as "winners" increasingly resemble one another while "losers" (i.e., those unable or unwilling to adapt new innovations) are eliminated through conquest (Posen 1993; Mearsheimer 2001).According to this view, polities outside the West were maladapted, and had to either emulate superior Western models, or be selected out through conquest and colonization. Fazal notes that this view of elimination of maladapted units via military competition is a vital, but often only implicit, plank of the realist position (2007: 4, 60-61).

This realist military Darwinism accords with a major body of literature in sociology and history that credits war as the engine of state formation in late medieval and early modern Europe. Parker is succinct in explaining how this perspective relates to the rest of the world: "the key to the Westerners' success in creating the first truly global empires between 1500 and 1750 depended upon precisely those improvements in the ability to wage war which have been termed ‘the military revolution'” (Parker 1988: 40).Even rationalists and constructivists who see military concerns as intervening variables mediating between economic or cultural factors retain important aspects of this Darwinian “survival of the fittest” narrative (See North 1990a; Ruggie 1998; Spruyt 1994). 
The second mechanism emphasizes economic factors, and puts greater weight on rational emulation, deliberate adaptation and learning, rather than elimination (Tracy 1990: 1; Pearson 1990). While military prowess may be a proximate cause of success in war (North 1990a: 24; Spruyt 1994: 21, 157-8, 178), these scholars focus on the economic determinants of military power. Thus for North and Thomas: "the development of an efficient economic organization in Western Europe accounts for the rise of the West” (1973: 1).In writing on the early modern Indian Ocean, North holds that increasing volumes of trade and efficient institutions reinforced one another (North 1990b: 127). Subsequently, "international competition provided a powerful incentive for other countries to adapt their institutional structures to provide equal incentives for economic growth” (North and Thomas 1973: 157).North’s later work is devoted in part to explaining the persistence of inefficient institutions, but nevertheless he maintains: "Polities and economies struggled, not only inside Europe for hegemony but also in the growing empires of the rest of the world, where competition played the critical role... of inducing increased efficiency" (North1990a: 26).

Though Spruyt's sophisticated explanation of why states won out over trading leagues and city-states relies in some measure on each of the three mechanisms, there are pronounced similarities with North. States enjoyed key advantages in preventing free-riding and lowering transaction costs in domestic and foreign exchanges. At this point, "War did not work as an evolutionary process that selected among types of units, but it did indicate to political elites and social groups which type of social organization was the more efficient, and they subsequently adopted the most competitive institutional form” (Spruyt 1994: 178).

Though we subsequently employ a modified constructivist thesis, some constructivists also subscribe to the interaction-convergence hypothesis. As such, the final mechanism is 
socialization, understood as organizations looking to enhance their legitimacy via mimicry of perceived leaders or models. Units adapt themselves to more closely resemble appropriate or valorized forms, and thereby bolster their prestige and esteem. One of constructivism's key insights is that international norms not only regulate the behavior of states in the international system, but also constitute those units (e.g., Weber 1994; Ruggie 1998).Strang argues that the worldwide expansion of European state system from 1415 was primarily explained by legitimacy concerns because the "cultural framework of the international system shapes state action”(1991: 146). Strang holds that the state is a product of a cultural selection process. Sovereign states constituted by mutual recognition were exempted from the military struggle for survival, while non-Western polities not enjoying the same recognition were conquered and colonized. We present a précis of these main theoretical approaches in the table below.

Table 1 Interaction Capacity and Unit Convergence in Mainstream IR Theories

\begin{tabular}{|l|l|l|l|l|}
\hline $\begin{array}{l}\text { Theoretical } \\
\text { Tradition }\end{array}$ & $\begin{array}{l}\text { Overarching } \\
\text { Logic }\end{array}$ & $\begin{array}{l}\text { Expected Outcome of } \\
\text { Increased Interaction } \\
\text { Capacity }\end{array}$ & $\begin{array}{l}\text { Mechanism of } \\
\text { Convergence }\end{array}$ & $\begin{array}{l}\text { Type of Social } \\
\text { Interaction } \\
\text { Promoting } \\
\text { Convergence }\end{array}$ \\
\hline Realism & Competition & Convergence & $\begin{array}{l}\text { Convergence } \\
\text { through } \\
\text { elimination }\end{array}$ & Military competition \\
\hline Rationalism & Competition & Convergence & $\begin{array}{l}\text { Convergence } \\
\text { through rational } \\
\text { emulation }\end{array}$ & $\begin{array}{l}\text { Economic } \\
\text { interaction } \\
\text { (especially increased } \\
\text { trade) }\end{array}$ \\
\hline Constructivism & Conformity & Convergence & $\begin{array}{l}\text { Convergence } \\
\text { through } \\
\text { socialization }\end{array}$ & $\begin{array}{l}\text { Spread of common } \\
\text { standards of } \\
\text { legitimacy }\end{array}$ \\
\hline
\end{tabular}




\section{Scope Conditions and Implicit Theories of Diversity}

The foregoing survey reveals a tendency within mainstream IR theories to causally associate increased interaction within international systems with a convergence on common polity forms. Before presenting evidence from the Indian Ocean system that challenges this claim, we must pre-empt two potential objections.

First, is it fair to test explanations developed with Europe in mind against evidence from a different region, like the Indian Ocean? We maintain that this move is justifiable, given that IR is neither European area studies nor contemporary history, but a social science, and that its practitioners frequently generate claims that are said to be transferable across different historical and geographical domains. For example, realists commonly claim that basic parameters of their theory apply largely independent of historical and geographical context (Waltz 1979; Mearsheimer 2001). Theorists relying on the intellectual tools of microeconomics are likewise drawing on an abstract framework at odds with the idea that historical or cultural specificities are determinative. North explicitly refers to the VOC in his discussions of lowering transaction costs (1990b), thus extending the empirical reach of his argument to encompass one of the Indian Ocean's primary polity forms. Turning to cultural explanations, Strang's data relate to the entire international system 1415-1987, including the Indian Ocean (1991), again suggesting the reasonableness of testing theoretical claims against non-European contexts.

The proper way to test purportedly general hypotheses developed from one source of evidence (e.g., European history) is against new and different evidence (e.g., another region) (Geddes 1990; King et al. 1994). It is perfectly legitimate for explanations to have scope 
conditions limiting their temporal and regional application (as ours does). But this hardly means that studies outside these limits are irrelevant. The argument here does not (and does not aim to) prove, for example, that Spruyt was wrong about European state-formation. But it is appropriate to compare and contrast our findings with existing theories to highlight regional similarities and differences, and to thus qualify the reach of their claims.

Second, critics might dismiss the preceding survey asa caricature. To clarify, we do not claim that all realists, rationalists, and constructivists argue that increased interaction produces convergence. To the contrary, below we draw out implicit or subordinate theories of diversity in each, and later employ key features of the constructivist work in this vein.

For realists, the distribution of qualitatively different types of military capabilities between polities might generate and then preserve diversity among them, at least for a time. Distinctions between terrestrial and maritime powers might enable the two to co-exist. Given realism's strong expectation of competition and elimination, however, the stability of such a coexistence would presumably be brief. The historical prevalence of protectorates between dominant and weaker actors shows that marginal actors can find unconventional methods of selfpreservation, which involve alienating portions of their sovereignty to stronger polities without being completely absorbed. Clientelist alliance formation thus provides a potential mechanism for reproducing diversity consistent with realism.

Rationalist approaches likewise contain resources capable of at least partially explaining durable diversity. Spruyt captures an initial period of speciation and ensuing polity diversity in late medieval Europe (1994). In Spruyt's case, the different social coalitions formed following the resurgence in long-distance trade generated distinct polity forms (city-states, city-leagues, 
and sovereign states), which only later converged toward a sovereign state monoculture.

Generalizing from Spruyt, one could argue that economic specialization favors the emergence of distinct social coalitions and correspondingly different polity forms. Cooley and Spruyt's work on the hierarchical transfer of sovereignty functions between polities meanwhile provides a potential mechanism explaining how polity diversity might reproduce itself over time (2009). Incomplete contracting and sovereignty transfers between polities may help to stabilize relations between diverse polity forms sharing economic complementarities.

Constructivists already recognize that historically and culturally contingent forms of collective identity may initially generate different polity forms. Likewise, while constructivists expect a logic of conformity to prevail among polities as their interaction grows, this need not mandate a corresponding uniformity of polity forms. On the contrary, constructivist understandings of empires as "regimes of unequal entitlement” provide a means of explaining how polity diversity may be reproduced over time (Reus-Smit 2011). Whether underwritten by consensus or by dominant polities’ coercive socialization of their vassals, regimes of unequal entitlement may allocate special bundles of privileges to different polities, giving rise to authority structures that lock in diversity rather than uniformity. Accounts like Acharya’s (2004) on localization also give room for diversity in focusing on norm takers' agency in reconstructing foreign norms.

\section{Explaining Durably Diverse International Systems - A Theoretical Account}


The implicit theories of diversity sketched above all rely in some measure on mechanisms that tacitly relax assumptions of territorial exclusivity in unbundling the package of sovereign prerogatives: protectorate arrangements, incomplete contracting, regimes of unequal entitlement. This move strongly suggests the possibility that a partial interweaving of layered and shared authority might prevail over elimination, emulation or socialization between sharply bounded units.

Building on this insight, our argument starts with the idea that polities constitute bundles of authority ties possessing "a distinct identity, a capacity to mobilize persons and resources for political ends, and a measure of institutionalization and hierarchy” (Ferguson and Mansbach 1996: 262). Theoretically, this view is influenced by Ruggie's attention to the principle of separation between units, or the lack of, as a defining feature of international systems (1983, 1998). It is also a close fit with relational institutionalist approaches that take boundaries between polities as something to be explained, rather than simply assumed (Jackson and Nexon 1999; Nexon 2009). In relaxing the idea of territorial separation as a defining feature of political authority, we are able to better understand the diverse polity forms that populated the early modern Indian Ocean international system, and the nature of their inter-relationships.

We argue that diversity in the Indian Ocean system developed first because European and local polities possessed different preferences for maritime versus land-based conquest. Competition did not drive homogenization because the system's most significant actors, European maritime polities and Asian land-based empires, were not competing. Rather than reflecting a post hoc adaptation to the asymmetric capabilities of sea versus land-based powers, these coincidentally complementary preferences were culturally ingrained. They pre-dated the first encounter between the Europeans and locals in the Indian Ocean, and proved durable even 
as Europeans interacted ever more intensely with local polities. These different but complementary preferences muted pressures for convergence through competitive elimination, and created the opportunities for European insertion into the region, so establishing the first main pre-condition for durable diversity.

The second factor that enabled durable diversity was that Asians and Europeans shared similar traditions of heteronomy. According to Ruggie, heteronomy is "a patchwork of overlapping and incomplete rights of government," under which "the distinction between 'internal' and 'external' political realms, separated by clearly demarcated 'boundaries,' [makes] little sense” (1983). Equivalent commitments to heteronomy made it possible for Europeans to share authority with local polities, further assisting European insinuation into the region. Indian Ocean littoral societies had long-standing heteronomous traditions. These traditions helped to accommodate the merchant diasporas that mediated long-distance trade by granting them rights of residence and limited self-government in exchange for their deference to local authorities (Chaudhuri 1985; Bose 2009). Likewise, European intruders came from a system that had been defined by heteronomy throughout the Middle Ages, and where notions of sovereign-territorial exclusivity were still only nascent (Spruyt 1994; Ruggie 1998).

Congruent European and indigenous traditions of heteronomy - much like their complementary preferences for either maritime or territorial conquest - pre-dated first contact. They were not engineered as part of a deliberate strategy to mediate European-Asian relations. This mutual familiarity with heteronomy was nevertheless crucial for solidifying polity diversity in the Indian Ocean. It provided a means to spatially organize European-local relations that could support increased interaction, without requiring convergence on polity forms through reciprocal territorial exclusion, as in early modern Europe (c.f. Spruyt 1994). Because Europeans and locals 
both had independent prior experiences of heteronomy, this meant they could work together to partially weave European polities into indigenous political and economic networks, without requiring polity convergence.

Regional diversity was not, however, guaranteed by a combination of diverse preferences and congruent traditions of heteronomy. Heteronomy in medieval Europe had rested on a religious cultural consensus of shared constitutional norms. Ruggie notes: "the medieval system of rule was legitimated by common bodies of law, religion and custom expressing inclusive natural rights” (Ruggie 1993: 150). No equivalent consensus existed in the Indian Ocean system. Equally, European and local actors did not divide authority among one another according to a coherent overarching logic of functional differentiation. Instead, Europeans generally shared power with locals by slotting into indigenous hierarchies, alternating as vassals, partners or suzerains, depending on local contexts. Despite their status as cultural outsiders, Europeans managed to stabilize and legitimize their enmeshment in local polities through practices of localization. Drawing on Wolters' use of localizationin Southeast Asian history, this concept refers to the practice of selectively appropriating, reinterpreting, and reconciling foreign ideas to better align them with local contexts and circumstances (Wolters 1982). Acharya uses this term to describe "a process of idea transmission in which... borrowed foreign ideas about authority and legitimacy and fitted... into indigenous traditions and practices”(2004: 244). Importantly, however, in this study localization was practiced by outsider Europeans adapting to local norms and practices. Thus in explaining Britain's later conquest of India, Paul MacDonald notes "the British used the iconography of the previous [Mughal] system to lower the social costs of collaboration” (MacDonald 2014: 88). In a similar vein, practices of localization were crucial in 
easing Europeans into existing local hierarchies, as either vassals or suzerains. For host polities, localization legitimized the incorporation of outside elements into existing authority networks.

Our argument is therefore explicitly constructivist in three senses. First, we argue that ideas shape actors' preferences and the purposes they pursue. Different but complementary preferences forestalled convergence through either elimination or emulation, and so made a diverse order possible. Second, congruent conceptions of heteronomy enabled a durable sharing of authority between unlike polities. Third, ideas stabilized shared authority arrangements between diverse polities. In the absence of a pre-existing cultural consensus, actors' willingness to legitimize plural and diverse authority arrangements through resort to localization is key to determining the longevity of diverse international systems.

Given all the above, under what conditions would we expect durable diversity instead of convergence within an international system? As well as diverse preferences, deep yet flexible traditions of heteronomy that can be taken from one context and applied within another represent important enabling conditions. So too is actors’ ability and willingness to adapt locally dominant idioms of rule so as to legitimize heteronomous and hybrid authority arrangements. The argument presented here is both superior to alternatives in accounting for the particular outcome (durable diversity in the Indian Ocean), while more broadly suggesting mechanisms to explain the neglected prevalence of diverse international systems more generally.

Having outlined the argument in its sparest form, and situated it within the relevant scholarship, it is now time to consider the evidence. The empirical material in the remainder of the article has three aims. First, we seek to introduce the Indian Ocean system, substantiate the claim about increasing interaction, and establish the diversity of the statist, imperial, and corporate polities that comprised this system. Our second goal is to support the thesis sketched 
above, that pre-existing contrasting preferences and shared commitments to heteronomy, coupled with practices of localization, produced a durably diverse international system. Third, we consider potential objections and alternatives. In particular, we critique the idea that early modern diversity was a 250-year anomaly, which was subsequently erased by a delayed convergence of polity forms exemplified in the rise of European colonial empires after 1750. Colonialism undoubtedly represented a shift in the configuration of regional polity diversity. But the path-dependent legacies of earlier heteronomous arrangements thwarted European efforts to modernize and standardize local polity forms during the colonial era. This ensured diversity's persistence down to twentieth century decolonization, and the advent thereafter of a regional sovereign state monoculture.

\section{Diversity in the Early Modern Indian Ocean}

The climatic regularity of the monsoonal winds and a near-continuous littoral favored the Indian Ocean's early emergence as zone of inter-regional exchange. Trade further expanded from the seventh century, following the consolidation of political stability spurred by Islam's rise in West Asia and the T'ang Dynasty's emergence in China (Chaudhuri 1985). Though dominance in merchant shipping thereafter alternated between Persians, Arabs and Chinese, the Indian Ocean was too big for anyone to politically dominate (Frost 2008: 44). Instead, before the Europeans' arrival, maritime trade remained demilitarized, and centered on relatively autonomous port cities connected by extensive merchant trading diasporas, who enjoyed limited self-government under region-wide customs of commercial extra-territoriality. 
The sixteenth through eighteenth centuries saw interaction capacity and polity diversity surge throughout the Indian Ocean. Commercially, the Europeans’ arrival kick-started the direct Europe-Asia trade, which grew twenty-five fold in the three centuries to 1800 (de Vries 2010: 718). Moreover, the Europeans found that to pay for Asian merchandise, they had to generate profits by intra-regional trade, for example between Gujarat and the Swahili Coast of Africa, or Bengal and archipelagic Southeast Asia (Boxer 1969; Chaudhuri 1985; Pearson 1990;

Subrahmanyam 2012). By volume, more European trade was intra-regional than extra-regional. The Europeans also brought expertise in boat building, navigation and gun founding, enhancing the region's physical interaction capacity. On land, meanwhile, the Mughals also gave a strong fillip to land-based trade, by maintaining peace through the empire, increasingly monetizing the economy, and initiating an extensive road building program (Richards 1993; Alam and Subrahmanyam 1998; Streusland 2011). Rather than proceeding in isolation, the increased exchange of goods and ideas by sea and land reinforced each other, knitting the region together in ever-denser networks of exchange.

Not confined to commerce, interaction within the early modern Indian Ocean also surged on the military, diplomatic and cultural fronts. Once the Dutch and English joined the Portuguese from the early 1600s, the Europeans fought for maritime supremacy across the length and breadth of the region, integrating it as a coherent strategic space. But even before this European competition, Portuguese expansion had already sparked indigenous resistance to the 'Franks.' The sultanate of Malacca's embassies to the Ottoman Porte during this time reflected a broader trend, whereby Portuguese bellicosity inspired Muslim-majority polities to diplomatically coordinate opposition to their common enemy (Reid 1969). 
The growth in interaction capacity within the early modern Indian Ocean was thus substantial and multifaceted, encompassing war and diplomacy as well as commerce and culture. It moreover played out amidst growing polity diversity, evidenced in the arrival of the era's three most consequential polity forms - the state-like Estado da India, the Mughal Empire, and the Dutch and English company sovereigns.

\section{The Portuguese Estado da India}

Only seven years after Vasco da Gama first reached India, the King of Portugal established the viceroyalty of the Estado da India in 1505. After an explosive period of conquest in the next decade, the Portuguese controlled a network of forts and ports from Mozambique, to the Persian Gulf, to Malacca and the Spice Islands, with further trading posts in China and Japan. These entrepots, and the whole Indian Ocean, were claimed for the Portuguese King, to be ruled by his representative in Goa. Although not matching the ideal type of the modern sovereign state, the resulting structure has been described as "precociously statist” (Wills 2000: 354). The Portuguese favored a centralized structure of authority that flowed directly from the king, to the governor of the Estado da India, and then to his subordinate officials, and extended in scope to military and commercial as well as administrative affairs. Certainly these arrangements were far closer to the sovereign state ideal than either the Mughal Empire, with its heterogeneous rule through intermediaries, or the Dutch and English private-public Company sovereigns. Bethencourt notes: "The model of centralized power delegated by the king... was applied from the very start of the Portuguese expansion in Asia”(2007: 221). The consistent goal was to make local agents responsible to their royal and viceregal principals. 
Payment for garrisons and forts came from central funds (Tracy 1990: 9). There was no equivalent of the VOC or EIC private armed forces, or the Mughals' quasi-feudal organization of military power. The same went for naval forces: "The Portuguese ships and the guns were primarily owned by the state. This makes the Portuguese enterprise look strikingly modern” (Glete 2000: 89).For most of the sixteenth century trade too was a centralized state monopoly, with both bullion and spices being reserved for royal agents (Boxer 1969: 60). Even after this point, merchants were subordinated to royal interests (Chaudhuri 1985: 71; Glete 2000: 87).

Unsurprisingly, royal and vice-regal ambitions to control their agents far out-stripped their ability to enforce their wishes over vast distances and with the technology of the day; public officials often shirked their duties, while merchants surreptitiously evaded the royal monopoly. But the Portuguese never abandoned their centralized, statist model. The strict vertical chain of command, the pattern of direct appointment from the administrative center, and the public control of military and economic prerogatives gave the Estado da India a modern, statist feel that is entirely lacking from the imperial and corporate models that eclipsed (though did not eliminate) it from the seventeenth century.

\section{The Mughal Empire}

The Mughals emerged from Central Asia to conquer most of South Asia from 1526. By 1650 their empire included more people (approximately100 million) and greater fiscal and military resources than every state in Christian Europe combined (Pearson 1990; Richards 1993).Like all empires, the Mughal Empire was a “regime of unequal entitlement,” cohering around "institutional frameworks that allocate[d] individuals of different social status different social powers and entitlements” (Reus-Smit 2011: 207). We follow Nexon and Wright's 
contention that the defining difference between empires and the states is that the former govern by heterogeneous contracting with intermediary rulers (Nexon and Wright 2007: 259).

The imperial court relied extensively on local intermediaries to uphold its rule. The empire was organized in the form of "looser, cascading political structures [that] espoused layered and shared sovereignty with lower-level leaders” (Bose 2009: 70). This reliance on local clients and "heterogeneous contracting" (Nexon 2009: 72) empowered emperors to extend their paramountcy over a huge number of subordinate polities (Bayly 1989). But this paramountcy was not equivalent to modern sovereignty, being more fluid and territorially uneven in its application (Benton 2010). The sharp domestic/foreign distinction that is fundamental to modern sovereignty was lacking. Nor did the Mughals acknowledge any international equals, instead maintaining that their rightful authority extended without any limit (Gommans 2002: 20).

While enjoying access to formidable military power resources, the Mughals neither sought nor attained a monopoly of legitimate violence. The local elites who acted as the Mughals' tax-farmers collectively retained autonomous command of over 300,000 horsemen at the height of Mughal power in the mid-seventeenth century. India's stock of over 2.5 million armed peasants routinely sold their services to both the Mughals and other masters (Asher and Talbot 2006: 128; Peers 2011: 98). In contrast to the Portuguese, the Mughals were thus much more reliant on autonomous intermediaries, and a loose, shared model of graduated authority to exert their authority and summon military force, supplemented by the market.

\section{The Dutch and English East India Companies}

The Dutch and English East India Companies were hybrid actors without modern equivalents. The VOC and EIC were private, joint stock enterprises that also enjoyed key 
sovereign prerogatives and wielded extensive armed force. The EIC was invested with powers including the right to administer civil and criminal justice, to maintain armies and a navy, and to enforce its monopoly against European and Asian interlopers and pirates by force (Lawson 1993: 29). Similarly, the VOC could sign international treaties, declare war, make peace, and maintain military and naval forces. It could mint its own coins, establish colonies, and administer criminal justice (Thomson 1994; Ward 2008). Yet both were very definitely also private companies, owned by shareholders and run for profit (Steensgaard 1973; North 1990b; Ward 2008; Stern 2011). The Companies’ hybrid commercial-military nature was epitomized in a report from one of the VOC's most combative governor generals, Jan Pieterszoon Coen, to the Directors in 1614: "Your Honors should know by experience that trade in Asia must be driven and maintained under the protection and favor of Your Honors' own weapons, and that the weapons must be paid for by the profits from the trade; so that we cannot carry on trade without war nor war without trade” (Quoted in Boxer 1965: 96).

Rather than trying to assert a monopoly on legitimate violence, EIC and VOC factors cultivated local vassals, hired mercenaries, and rendered tribute to the Mughal Emperor to secure their factories from attack. Their domains were constituted of multiple overlapping structures of authority, which projected jurisdictional claims unevenly across a networked archipelago of trading entrepots across the Indian Ocean (Stern 2011: 208).

Yet if the companies were not sovereign states themselves, neither were they mere extensions of the English or Dutch state. English subjects in Company territories were subject to EIC rather than Crown jurisdiction, company territories remained the property of the EIC rather than the English Crown, and the company engaged in diplomatic transactions with both European and Asian powers that occasionally ran contrary to the interests of the English 
monarch. Similarly, the VOC was no servant of the United Provinces. In 1644, the company informed the government: "The places and strongholds which they had captured in the East Indies should not be regarded as national conquests, but as the private property of merchants, who were entitled to sell those places to whomsoever they wished, even if it was to the King of Spain, or to some other enemy of the United Provinces” (Boxer 1965: 45).The companies’ autonomy rested on their status as interstitial entities drawing simultaneously upon multiple sources of authority, both European and Asian. Not only did the companies thus instantiate diversity themselves, they promoted it in others.

\section{Contrasting Preferences, Heteronomy, and Localization: The Evidence}

\section{Diverse Preferences on War and Trade: Mughals on Land, Europeans at Sea}

Given the Mughal Empire’s vast wealth, population and military capacity, how did Europeans become established in the region? And why did interaction between empire, state, and company consolidate and extend polity diversity, rather than fostering convergence on a common polity form? The first part of the answer is that Mughals and Europeans had different but complementary preferences regarding war and trade that long pre-dated their first encounters. These different preferences - anchored in European maritime versus Mughal terrestrial orientations- first enabled European expansion into the region. What Europeans most valued the Mughals did not want, and vice versa. 
European naval superiority was not reducible to technological factors. Instead, it reflected deep differences in European and local preferences concerning the relative value of maritime versus territorial conquest. Rather than technology per se, it was polities' differing ends that were most important in shaping the military relations between them. The Mughals were a landbased empire, like the Ottomans, the Persian Safavids, and further afield the Chinese. The vast Ming Dynasty treasure fleets of the fifteenth century prove that Asians were eminently capable of projecting long-range maritime power when they chose to do so. But the Mughals had little interest in building maritime trading empires or pursuing blue water naval expansion: "The whole mind-set of the Mughal emperors and their nobles was land-based. Prestige was a matter of controlling vast areas on which were located fat, meek peasants. Glory was to be won by campaigns on land” (Pearson 1990; see also Subrahmanyam 2007: 1373).Consequently, the Mughals preferred to pay off the Europeans through conceding trading privileges to them, rather than contesting their mastery of the sea (Gommans 2002: 164).

In contrast, the Europeans had little interest in building territorial empires (Ricklefs 1993; Kian 2008; Benton 2010). From the very beginning they had concentrated on conquering a network of critical ports like Hormuz and Malacca. Thus the Portuguese possessions comprised a "thalassocracy... generated by or subordinate to the Portuguese Crown, all of which were linked together as maritime network” (Subrahmanyan and Thomas 1991: 304; see also Bethencourt 2007: 199; Chaudhuri 1985: 14; Disney 2009: 146). The Estado da India gained 85 percent of its revenue from customs dues paid on seaborne trade and "protection fees" the Portuguese extracted from all others using sea lanes under its control (Disney 2009: 156). Similarly, the EIC's objective of establishing exclusive territorial control over strategically important areas was "an incidental aim of imperial expansion,” secondary to the goals of protecting the Company’s 
long-distance trading networks, policing its trading routes, and manipulating local political dynamics to exclude its European and indigenous commercial rivals (Benton 2010). The VOC was very similar (Boxer 1965; Ricklefs1993; Kian 2008).

Underwriting these different preferences lay different European versus local constructions of oceanic space. Harking back to Mediterranean precedents, Europeans saw seas and oceans as legitimate spaces for political contestation and objects of stewardship (Steinberg 1990: 75). Within the Indian Ocean, the symmetry in European conceptions of oceanic space helped drive their violent competition for maritime dominance. Conversely, Mughal indifference to naval affairs reflected in an extreme form an outlook more general throughout the Indian Ocean's indigenous societies, which constructed the ocean as an asocial medium for trade and cultural exchange (Steinberg 1990: 46). Local societies were hardly indifferent to the Indian Ocean. The idea that terrestrial polities could legitimately extend authority claims into the ocean, much less enforce them through deploying navies, was nevertheless alien. This belief endured even after Europeans had shown the plausibility and profitability of oceanic conquest.

These heterogeneous, compatible preferences undermine a basic assumption informing mainstream IR expectations of convergence: that because actors are locked in competition to attain similar ends, they are compelled to adopt similar institutional forms. Different outlooks, anchored in different conceptions of oceanic space, informed different ends and generated different polity forms, so fostering diversity. This emphasis on the constructivist foundations of these diverse preferences is important not only for our positive argument, but also because it distinguishes us from a potential realist alternative, which would reduce polity diversity merely to the absence of elimination pressures between maritime and terrestrial powers. Against this position, we argue that competitive pressures are in fact endogenous to actors' constructions of 
strategic space. With different conceptions of strategic space, the realist mechanism of convergence through elimination is unlikely to come into play, regardless of increasing interaction. These different preferences not only forestalled the onset of symmetrical pressures of competition between them, so muting a process of convergence through elimination. Rather, they also helped to create the conditions for persistence of diversity under conditions of increasing interaction.

Divergent oceanic versus terrestrial preferences thus facilitated the entry of diverse European polities into the Indian Ocean. But they by no means guaranteed a durable diversity. Europeans needed coastal enclaves to maintain their oceanic empires; they could not simply float off shore entirely separate from terrestrial empires such as the Mughals. A partial enmeshment between European maritime and Asian terrestrial polities stabilized diversity and supported interaction. Congruent traditions of heteronomy helped make this possible.

\section{Empire, Company and Heteronomy}

Rather than driving convergence towards the sovereign state model (or any other), the company sovereigns further expanded the Indian Ocean region's diversity following their arrival in the1600s. They did so by meshing with similarly heteronomous local actors. Upon first entering the Indian Ocean region, the companies benefited from partially subordinating themselves to different Asian and European powers to maximize their legitimacy with different audiences, and their autonomy vis-à-vis any one master. In relating to the region's smaller polities, the companies consolidated control by establishing systems of indirect rule that guaranteed them political and commercial privileges, excluded European rivals, and deflected the costs of rule and administration on to local authorities. 
The companies operated at the intersection of European and Asian systems of authority. They did so first by dint of chartered monopolies granted them by "home" governments, and second through privileges company agents extracted from locals through their own war-making and diplomacy. This simultaneous dependence on many masters actually strengthened the companies’ autonomy by enabling them to leverage multiple sources of authority and legitimacy (Stern 2011: 13-14).The companies were therefore well positioned to extract privileges from potentates as diverse as the King of England, the Netherlands States-General, and the Mughal emperor. As vassals of multiple suzerains, the resulting tensions increased the companies’ ability to tack between multiple allegiances as interests dictated. By contrast, the Portuguese enjoyed less flexibility and eventually less success, as their hierarchical structure extended to the Portuguese king, who brooked no superiors.

The EIC in particular solicited the Mughal emperor's patronage to secure a foothold in India, eventually insinuating itself into the Mughal empire's administrative structure as a revenue administrator and vassal to the emperor (Bryant 1985: 4). By contrast, the more classically statist Portuguese tried to interact with the powerful Asian rulers on a basis of equality. Beyond the Indian Ocean, the Chinese found these pretensions to equality so offensive that they beheaded some of the first Portuguese delegation (Disney 2009: 142).

Company sovereigns' heteronomous configuration also enabled them to extend suzerainty over many smaller local polities. The utility of such arrangements - in leveraging local legitimacy and minimizing administration costs - is revealed in EIC officials' assessments of the governance arrangements established in their Sumatran factory of Bengkulu: 
The way to govern those people, is to govern them by petty Kings of their own, whom you must honour before the people and make them your instruments to keep the people in subjection while you governe [sic] them and keep them in dependence of you (quoted in Stern 2011: 96).

Instrumental considerations of autonomy, flexibility and economy were important in explaining why the company sovereigns preferred hybrid heteronomous arrangements. Yet this does not explain how the company sovereigns managed to institutionalize these deals, given the cultural differences separating them from local actors. We argue that company sovereigns' preferences for hybrid arrangements and local actors' receptivity can be partially explained by the pre-existence of congruent traditions of heteronomy between them.

Customs of commercial extra-territoriality, whereby merchant diasporas enjoyed limited rights of self-government while remaining subordinate to indigenous potentates, were widespread throughout the Indian Ocean littoral (Benton 2011: 57-59). Likewise, Europeans had their own experience of the heteronomy that defined Latin Christendom. Benton in particular has argued that Europeans' prior experience primed them to adopt heteronomous regimes over the course of European expansion (1999: 567). While differing dramatically from the state and one another in their overall forms, company sovereigns and empires were therefore similar inasmuch as each had multiple, overlapping, and fluid authority structures. This commonality enabled company sovereigns to enmesh themselves within local polities, either as suzerains or vassals.

For example, the company sovereigns secured trading privileges from the Mughal Emperor only by agreeing to become Mughal vassals (Stern 2011: 13). What seems from a contemporary perspective to be a loss of Mughal sovereignty was thus perceived at the time as a 
revocable concession, consistent with long-established customs of commercial extra-territoriality (Alexandrowicz 1967: 98-99).This local cultural context thus facilitated European entry, and then much later legitimized the EIC’s increasingly dominant role within the Mughal political order. An equivalent dynamic obtained between the companies and minor South Asian rulers, this time with the Europeans as suzerains. Thus after ousting the Portuguese from Cochin on India’s Malabar Coast in 1663, the company arranged the coronation of a new Raja with a golden crown conspicuously stamped with the VOC design (Mostert 2007: 121).

The evidence above underlines the central importance of territorial non-exclusivity, of the fluid and inter-leaved frontiers of polities in the region, in contrast to the conventional IR understanding of sharply-bounded like units, and an equally sharp distinction between international anarchy and domestic political authority. While some of the implicit theories of diversity canvassed earlier do bring the conventional wisdom into question, they do not focus on the principle of separation as does Ruggie, relational institutionalist scholarship, and the explanation presented here.

This principle of (non)-separation is so important because rather than diversity in the Indian Ocean region being merely the persistence of freestanding diverse polities, characterized by discrete external boundaries and reciprocal spatial exclusion, it was instead dependent on the sharing of authority between overlapping polities. The contrast with rationalist accounts here is significant. Rationalists might be able to explain why European and indigenous polities failed to converge, but they are less able to explain how they came to merge. One could mount a rationalist argument that diversity endured simply because European and indigenous polities possessed different preferences, and therefore faced few compelling incentives to converge to common forms through competitive emulation. Such an explanation could potentially explain the 
absence of convergence between discrete units. What it cannot do is explain the enmeshment of durably diverse European and indigenous polities that we observe in the Indian Ocean region. Understanding this process demands an awareness of how European company sovereigns and local empires took advantage of congruent traditions of territorially non-exclusive rule to create the hybrid forms of authority that mediated their increased interaction.

Both the structure of complementary preferences and congruent traditions of heteronomy formed separately and independently among European and Asian actors. The first enabled them to co-exist. The second enabled them to institutionalize their relationships in territorially nonexclusive shared authority arrangements. But how were they able to legitimize and thus stabilize the resulting arrangements, given the lack of consensus on common values, and sometimes sharp cultural antagonisms? The answer depends on agency-centered practices of localization.

\section{Localization and Legitimacy}

How was a diverse system, comprised of diverse European and Asian polities, able to survive for so long without a common worldview and shared belief system? This element of the puzzle is particularly important, given the importance Ruggie accords to a shared system of legitimation in stabilizing heteronomy in Medieval Europe (Ruggie 1998: 151). For Ruggie, heteronomy lasted so long in Europe in part because it rested on a common religious cultural worldview. No comparable consensus existed to stabilize heteronomous arrangements between Europeans and locals in the Indian Ocean region. Without this consensus, Europeans and locals stabilized their relations instead through practices of localization, whereby parties manipulated local idioms of rule to legitimize Europeans' partial incorporation into indigenous polities. 
Variations in indigenous ideas of rule shoved and shaped the nature of European incorporation into local polities, compounding diversity.

Two contrasting examples illustrate localization's importance in conditioning the nature of European incorporation. Within the Mughal Empire, the EIC won acceptance into Mughalruled entrepots by appealing to the language of universal rulership legitimizing the Emperor's authority. Mughal ideas of rulership were universalistic, incorporative and ecumenical. The Mughal emperor's authority was theoretically without limit. He could not engage with Europeans on terms of diplomatic equality, but demanded their ritual submission as tributary vassals as the price of imperial generosity. But at the same time, Mughal ideology conceived the Emperor as one who embraced cultural difference. As "king of kings" he was the solar center uniting and reconciling diverse lesser sovereigns (Richards 1993; Alam and Subrahmanyam 1998; Gommans 2002; Khan 2009). Provided Europeans acknowledged Mughal suzerainty, then, their very exoticism as distant vassals could strengthen Mughal power, by reaffirming the universal and cosmopolitan reach of the Emperor's authority. This gave Europeans a key point of ideational entry into the Mughal Empire, which they proved adept at exploiting.

As supplicants to the Mughal court, company agents performed a rite of prayer to petition the Emperor for trade privileges. This rite involved a highly ritualized exchange of gifts between the Emperor and company agents, intended to affirm the latter's status as "slaves" to the Emperor (Siddiqi 2005: 11). Europeans found this ritual unfamiliar and humiliating. Nevertheless, their eventual participation won them recognition as vassals, and an edict that guaranteed their trading rights against both European and local competitors. The Mughal Emperor also benefited from the arrangement, the homage of distant Europeans seeming to further confirm the universal remit of the Emperor's power. The increased commerce and 
customs receipts EIC activity meanwhile generated cemented a distrustful symbiosis between Company agents, local traders, and tax-farming Mughal officials, further easing the EIC’s integration into indigenous commercial and political networks.

By contrast, both the EIC and the VOC localized in archipelagic Southeast Asia by assimilating to indigenous "stranger king” traditions that primed local societies for foreign rule (Ricklefs 1993; Kian 2008). In archipelagic Southeast Asia, polities co-existed in a series of fluid and overlapping circles of suzerainty and vassalage. Here, rulers commonly professed allegiance to multiple suzerains, while potentially also claiming suzerainty over their own tributaries. In particular, "stranger king” norms permitted local rulers to embrace foreign suzerains as a means of strengthening their own authority. Invoking the language of fictive kinship, indigenous rulers would bind themselves to foreign suzerains. In exchange, "stranger kings" legitimated their vassals.

Once they became familiar with these local "stranger king” norms, the company sovereigns skillfully exploited them to insert themselves adopt indigenous hierarchies. Writing of the terms of diplomatic correspondence between the VOC and its indigenous allies, historians have noted that the Company, "though a large bureaucratic apparatus, was approached in a personified way,” with titles such as 'father' and 'grandfather' reflecting an imagined familial relationship linking Dutch suzerains to local vassals (Van Goor 1985: 196). Similar terms pervaded diplomatic correspondence between the EIC and its local allies across the Indonesian archipelago. That the company sovereigns readily supplied their vassals with mercenaries, firearms and credit further ingratiated them with local rulers. At least while their suzerainty remained symbolic and generally unobtrusive, the company sovereigns' willingness to play the 
"stranger king" role was critical in legitimizing and stabilizing their relationships with indigenous polities.

Whether as humble vassals or benevolent suzerains, Europeans were most successful in interweaving company authority into indigenous polities when they adapted to existing idioms of rule through localization. Strategies of localization - not socialization in line with any shared worldview-supported heteronomy in the Indian Ocean region. In both Mughal India and archipelagic Southeast Asia, European willingness to serve as either vassals or "stranger kings" strengthened the power and authority of indigenous actors (at least for a time), while cementing European participation in local political and economic networks. The same mechanism of mutual empowerment through localization was therefore present in both cases. Differences in local idioms of rule (universal kingship versus “stranger king” traditions) nevertheless produced diverse relationships between local polities and company sovereigns, reproducing polity diversity. While European and local actors possessed different but complementary preferences for oceanic versus land conquest; while their embrace of territorially non-exclusive rule preserved possibilities for mutual enmeshment; and while both sides remained willing and able to legitimize their bespoke bargains through localization, a durably diverse international system endured.

Durable Divergence or Delayed Convergence? The Indian Ocean System After 1750 
What of the potential objection that diversity is an artifact of the time period selected? Is the analysis confined to a period of speciation rather than selection, comparable to late medieval Europe's diversity before the triumph of the sovereign state?

We reject this critique on two grounds. First, it artificially brackets periods of speciation from selection. In the Indian Ocean, the two processes played out simultaneously without producing convergence on the sovereign state. The lack of convergence on forms that bore a closer resemblance to the sovereign state cannot be ascribed to the absence of a local statist model. Though not perfectly fitting the ideal-typical conception of the sovereign state, the Estado da India was organized on recognizably statist lines, certainly much more so than the Mughal Empire or the companies. But this statist model did not demonstrate any innate superiority over its imperial and corporate rivals; if anything, the reverse was the case. The historical consensus is that the company sovereigns were better at managing transaction costs and principal-agent problems than the Portuguese (Steensgaard 1973; Blussé and Gaastra 1982; North 1990b; Disney 2009). Normatively, company sovereigns' heteronomous traditions also made it easier for them to enmesh themselves with indigenous polities.

Second, the region's evolution to the mid-twentieth century in any case fails to vindicate a narrative of delayed convergence on the sovereign state. Certainly, the region saw far-reaching changes with the rise of large territorial colonial empires after 1750. Before this transition, polity diversity had rested on the ideational trinity sketched above: different European and local preferences; flexible sites of authority deriving from congruent traditions of heteronomy; and European and host actors’ willingness to pursue localization. 
After 1750, this ideational trinity dissolved, as European ambitions and ideas about legitimate political authority (both its territorial configuration and normative purpose) changed. Specifically, Europeans shifted from maritime to amphibious strategies of predation. They abandoned heteronomy for more territorially exclusive ideas of rule. Finally, they sought to standardize local authority arrangements along new, European lines. Accordingly, with these ideational changes, possibilities for elimination or violent subjugation through war rose, as Europeans began to fight large-scale land wars to seize territory from local rulers. Incentives for competitive emulation also increased, while earlier cross-cultural accords founded on localization faltered.

Yet the rise of large-scale European colonial empires did not produce a convergence on common polity forms. On the contrary, European efforts to abandon heteronomy and localization sparked violent indigenous backlashes, most notably the Java war (1824-1830) and the Indian 'Mutiny' (1857-59). The ferocity of this resistance and the immense costs of repressing it compelled Europeans to abandon their plans for standardization. Instead, they returned to practices of heterogeneous contracting and indirect rule that had earlier driven the company sovereigns’' expansion (Locher-Scholten 2004: 34; Rudolph and Rudolph 2010: 559).

The late eighteenth century switch to colonial domination reinforced diversity, albeit in a more hierarchical form. Heteronomy and localization enabled European and local polities' enmeshment in the early modern period, providing the institutional basis for expanded exchange between these polities. The high costs of changing the system, as the Europeans abortively tried to do, supports the argument about the durability of heteronomy. Consistent with historical institutionalist insights, an earlier reliance on congruent traditions of heteronomy and localization later locked Europeans in to a modified version of these arrangements. This was despite 
revolutionary changes in powerful actors' preferences (i.e. European colonialists), which agitated for the abandonment of heteronomy in favor of "rational state-building" (Buzan and Lawson 2013: 621) along more stereotypically modern sovereign-territorial lines (Bayly 1989, 2009; Benton 2010).

Colonial empires thus overlaid rather than displaced the plethora of local polity forms, refining and codifying rather than dispensing with the company sovereigns' earlier reliance on heteronomous indirect rule. To cite but one example, the British Raj enjoyed paramountcy over approximately six hundred 'native states', that ranged from huge states like Hyderabad, through to tiny principalities (some barely bigger than a fort and a town) in Rajputana. In this regard, then, the British colonial assessment that "[the] art of ruling native races is a thing of infinite variety not amenable to standardization” is typical (Newbury 2003: 73).

The implications of the colonial transition for our broader argument are as follows. In the early modern Indian Ocean, polity diversity first emerged and endured because of an ideational trinity composed of complementary but diverse preferences, congruent traditions of heteronomy, and improvised practices of localization. Once this ideational constellation dissolved, the pattern of diversity changed. A combination of newly symmetrical preferences, and European abandonment of heteronomy and localization, raised competitive pressures that yielded a new order built on large-scale European colonial empires. This power shift nevertheless did not drive a shift towards more uniform polity forms. Instead, the practical necessities of imperial rule forced a rapid reversion to heteronomy and localization as the basis for colonial order, preserving polity diversity in a modified form. The resilience of diversity in this context should not be equated with complete stasis; the shift towards colonial hierarchy did fundamentally re-shape the region. But the point remains that even once the ideational trinity favoring diversity dissolved, a 
combination of inertia and the imperatives of imperial governance ensured its reproduction throughout the remainder of the colonial era.

\section{Conclusion}

Examining the Indian Ocean region, we have argued against the conventional wisdom that increased interaction promotes convergence in polity forms. Different preferences, congruent traditions of heteronomy, and agents' willingness to pursue strategies of localization meant that increased interaction expanded and entrenched polity diversity. Unlike the European system, where sovereign anarchy eventually succeeded medieval heteronomy, in the Indian Ocean system the transition was to colonial empires.

There are two ways one might cash out the preceding insights. First, our explanation for the durable diversity in the Indian Ocean may offer insights translatable into other historical contexts. The Asian steppe, for example, saw nomadic pastoralist polities and sedentary civilizations interpenetrate from antiquity until well into the early modern period. Far from being dominated exclusively by war, relations between sedentary polities and nomadic "shadow empires” (Barfield 2001: 28) saw extensive trade and cultural exchange. Synergies between these polities may be attributable to different but complementary preferences and accompanying conceptions of territoriality. To take one example, the Mongol system of rule was generally not territorially fixed. Rather, political power resided in rulers' claims to control the cycle of migration over which their subjects and herds episodically traversed (Lattimore 1962: 535). Conversely, successive Chinese empires pursued wealth and power primarily through urban 
trade and the taxation of agriculture, and adhered to a territorially fixed but heteronomous configuration of authority characteristic of pre-industrial empires. This lent them a permeability that permitted an uneasy co-existence alongside nomadic pastoralists until the mid-eighteenth century, when a Chinese shift towards more exclusive conceptions of territoriality destroyed this old equilibrium (Perdue 2005: 270-289).

Colonial North America hosted a similar diversity of polity forms, from statist colonial outposts and Company sovereigns through to indigenous confederacies, especially around the Great Lakes region. Within this context, a "middle ground" of improvised practices, grounded in “creative, and often expedient misunderstandings”(White 1991: xxvi) of each others’ values, developed between Europeans and indigenes. Centered particularly on trade and makeshift security alliances, this “middle ground”(White 1991) echoed the more robust mutual empowerment through localization that sustained the Indian Ocean’s more durable diversity. But whereas contrasting but compatible preferences underwrote the Indian Ocean's diversity, a zerosum competition for land between settlers and Native Americans eventually doomed the socalled “middle ground.” This proved especially so after the Seven Years’ War, when settler colonialism displaced the fur trade as the main driver of European activity, and earlier models of land tenure and sovereignty yielded to more exclusive modern forms (Jones 2014: 132).

Second, what is the contemporary relevance of theories of durable diversity? There are good reasons to think that re-focusing on the principle of separation of units in the system will pay dividends. Cooley and Spruyt argue that sovereign prerogatives are increasingly split and shared between states in such a way as to create international arrangements that are neither strictly anarchical nor purely hierarchical (Cooley and Spruyt 2009: 6-8). In the security realm this might involve weaker states contracting out some of their sovereignty in return for protection 
from great powers (Lake 2009; Rezvani 2014). Lake argues that in order to see the importance of hierarchy in the contemporary international system we need to go back into history to recover the vocabulary of earlier diverse systems (2003: 303-304). Echoing this sentiment, some writing on empire suggest that we need to reacquaint ourselves with the way these historical forms worked to better understand power and hegemony in world politics today (Nexon and Wright 2007).

Whatever their differences, these scholars share a common dissatisfaction with the conventional picture of sharply-bounded sovereign state monocultures, on the grounds that this depiction is neither descriptively accurate nor theoretically productive in seeking to better understand world politics. Their common quest is to capture a more complex international order constituted by variegated polities defined by shared and overlapping chains of sovereign authority. This search for new theoretical perspectives complements other scholarship speculating on how the future international order may be shaped by Asian great powers able to negotiate on a more equal basis with their Western counterparts than they have in centuries. Current theoretical and geopolitical trends may indicate that the effort to look forward to future heterogeneous systems where the West is no longer dominant may be well served by looking back at the way such systems have worked in the past. 


\section{References}

Acharya, Amitav. 2004. How Ideas Spread: Whose Norms Matter? Norm Localization and Institutional Change in Asian Regionalism. International Organization, 58 (2), 239-275.

Alam, Muzaffar and Sanjay Subrahmanyam (Eds). 1998.The Mughal State 1526-1750, Delhi: Oxford University Press.

Alexandrowicz, C.H. 1967. An Introduction to the History of the Law of Nations in the East Indies $\left(16^{\text {th }}, 17^{\text {th }}\right.$ and $18^{\text {th }}$ Centuries). Oxford: Clarendon Press.

Asher, Catherine and Cynthia Talbot. 2006. India Before Europe. Cambridge: Cambridge University Press.

Barfield, Thomas J. 2001. The Shadow Empires: Imperial State Formation Along the NomadChinese Frontier. in Susan E. Alcock, Terence N. D’Altroy, Kathleen D. Morrison and Carla M. Sinopoli(eds.), Empires: Perspectives from Archeology and History. Cambridge: Cambridge University Press, pp. 10-41.

Bayly, Christopher. A. 1989. Imperial Meridian: The British Empire and the World, 1780-1830. London: Longman.

Bayly, Christopher A. 2009. The Military-Fiscal State and Indigenous Resistance: India 17501820. In The C A Bayly Omnibus. Oxford: Oxford University Press.

Benton, Lauren A. 1999. Colonial Law and Cultural Difference: Jurisdictional Politics and the Making of the Colonial State. Comparative Studies in Society and History. 41(3): 563-588.

Benton, Lauren A. 2010. A Search for Sovereignty: Law and Geography in European Empires 1400-1900. Cambridge: Cambridge University Press. 
Benton, Lauren A. 2011. Historical Perspectives on Legal Pluralism. Hague Journal on the Rule of Law. 3(1): 57-69.

Bethencourt, Francisco. 2007. Political Configurations and Local Powers', In Francisco Bethencourt and Diogo Ramada Curto (eds.) Portuguese Oceanic Expansion, 1400-1800. Cambridge: Cambridge University Press, pp.197-254.

Blussé, Leonard and Femme Gaastra (Ed.) 1981.Companies and Trade: Essays on Overseas Trading Companies During the Ancien Regime. Leiden: Leiden University Press.

Bose, Sugata. 2009.A Hundred Horizons: The Indian Ocean in an Age of Global Empire. Cambridge Mass.: Harvard University Press.

Boxer, C.R. 1965.The Dutch Seaborne Empire 1600-1800. New York: Alfred Knopf.

Boxer, C.R. 1969. The Portuguese Seaborne Empire 1415-1825. New York: Alfred Knopf.

Bryant, G. J. 1985. Pacification in the Early British Raj, 1755-85.The Journal of Imperial and Commonwealth History14(1): 3-19.

Buzan, Barry, and George Lawson. 2013. The Global Transformation: The Nineteenth Century and the Making of Modern International Relations. International Studies Quarterly 57 (3): 62034.

Chaudhuri, K.N. 1985. Trade and Civilization in the Indian Ocean: An Economic History from the Rise of Islam to 1750. Cambridge: Cambridge University Press.

Cooley, Alexander and Hendrik Spruyt. 2009. Contracting States: Sovereignty Transfers in International Relations. Princeton: Princeton University Press. 
De Vries, Jan. 2010. The Limits of Globalization in the Early Modern World.Economic History Review, 63 (3): 710-733.

Deudney, Daniel. H. 1995. The Philadelphian System: Sovereignty, Arms Control, and Balance of Power in the American States-Union, circa 1787-1861. International Organization 49 (2): 191-228.

Disney, A. R. 2009. A History of Portugal and the Portuguese Empire: Volume 2: The Portuguese Empire. Cambridge: Cambridge University Press.

Fazal, Tanisha M. 2007.State Death: The Politics and Geography of Conquest, Occupation and Annexation. Princeton: Princeton University Press.

Ferguson, Yale H. and Richard W. Mansbach. 1996. Polities: Authorities, Identities, and Change. Columbia S.C.: University of South Carolina Press.

Frost, Ellen L. 2008. Asia’s New Regionalism. Boulder: Lynne Reinner Publishers.

Geddes, Barbara. 1990. How the Cases You Choose Affect the Answers You Get: Selection Bias in Comparative Politics. Political Analysis. 2 (1): 131-150.

Glete, Jan. 2000. Warfare at Sea 1500-1650: Maritime Conflicts and the Transformation of Europe. New York: Routledge.

Gommans, Jos. 2002.Mughal Warfare: Indian Frontiers and the High Road to Empire 15001700. London: Routledge.

Hui, Victoria Tin-bor. 2005. War and State Formation in Ancient China and Early Modern Europe. Cambridge: Cambridge University Press. 
Jones, Charles. 2014. International Relations in the Americas During the Long Eighteenth Century, 1663-1820. In Shogo Suzuki, Yongjin Zhang and Joel Quirk (eds.) International Relations in the Early Modern World - Before the Rise of the West, pp. 118-137.

Kang, David C. 2010. East Asia Before the West: Five Centuries of Trade and Tribute. New York: Columbia University Press.

Khan, Iqtidar Alam. 2009. Tracing Sources of Principles of Mughal Governance: A Critique of Recent Historiography. Social Scientist 37 (5-6): 45-54.

Kian, Kwee Hui. 2008. How Strangers Became Kings: Javanese-Dutch Relations in Java 16001800.Indonesia and the Malay World36 (105): 293-307.

King, Gary, Robert O. Keohane and Sidney Verba. 1994. Designing Social Inquiry: Scientific Inference in Qualitative Research. Princeton: Princeton University Press.

Krasner, Stephen D. 1999.Sovereignty: Organized Hypocrisy. Princeton: Princeton University Press.

Lake, David A. 2003. The New Sovereignty in International Relations. International Studies Review. 5 (2): 303-323.

Lake, David A. 2009. Hierarchy in International Relations. Ithaca: Cornell University Press.

Lattimore, Owen. 1962. Studies in Frontier History. Oxford: Oxford University Press.

Lawson, Philip. 1993. The East India Company: A History. London: Longman.

Locher-Scholten, Elsbeth. 2004. Sumatran Sultanate and Colonial State - Jambi and the Rise of Dutch Imperialism, 1830-1907. Ithaca: Cornell University Press. 
MacDonald, Paul K. 2014. Networks of Domination - The Social Foundations of Peripheral Conquest in International Politics. Oxford: Oxford University Press.

Mearsheimer, John. J. 2001. The Tragedy of Great Power Politics. New York: W.W. Norton.

Mostert, Tristan. 2007.Chain of Command: The Military System of the Dutch East India

Company 1655-1663 MA Thesis, Department of History, University of Leiden.

Newbury, Colin W. 2003. Patrons, Clients and Empire: Chieftaincy and Over-rule in Asia, Africa and the Pacific. Oxford: Oxford University Press.

Nexon, Daniel. H. 2009. The Struggle for Power in Early Modern Europe: Religious Conflict, Dynastic Empires, and International Change. Princeton: Princeton University Press.

Nexon, Daniel H. and Thomas Wright. 2007.What's at Stake in the American Empire Debate. American Political Science Review 101 (2): 253-271.

North, Douglass C. 1990a. Institutions, Institutional Change, and Economic Performance. Cambridge: Cambridge University Press.

North, Douglass C. 1990b. Institutions, Transaction Costs, and the Rise of Merchant Empires, in James D. Tracy (Ed.), The Political Economy of Merchant Empires: State Power and World Trade 1350-1750. Cambridge: Cambridge University Press, pp.22-40.

Parker, Geoffrey. 1988. The Military Revolution: Military Innovation and the Rise of the West, 1500-1800. Cambridge: Cambridge University Press.

Pearson, M.N. 1990.Merchants and States. In James D. Tracy (Ed.)The Political Economy of Merchant Empires: State Power and World Trade 1350-1750.Cambridge: Cambridge University Press, pp.41-116. 
Peers, Douglas M. 2011.Revolution, Evolution or Devolution: The Military and the Making of Colonial India. In Empires and Indigenes: Intercultural Alliance, Imperial Expansion and Warfare in the Early Modern World, edited by Wayne E. Lee. New York: New York University Press, pp.81-106.

Perdue, Peter C. 2005.China Marches West: The Qing Conquest of Central Eurasia. Cambridge, Mass: Harvard University Press.

Posen, Barry R. 1993. Nationalism, the Mass Army, and Military Power. International Security18(2): 80-124.

Reid, Anthony. 1969. Sixteenth Century Turkish Influence in Indonesia. Journal of Southeast Asian History 10(3): 395-414.

Reus-Smit, Christian. 2011. Struggles for Individual Rights and the Expansion of the International System. International Organization 65 (2):207-242.

Rezvani, David A. 2014. Surpassing the Sovereign State: The Wealth, Self-Rule, and Security Advantages of Partially Independent Territories. Oxford: Oxford University Press.

Richards, John F. 1993. The Mughal Empire. Cambridge: Cambridge University Press.

Ricklefs, Merle.C. 1993.War, Culture and the Economy in Java, 1677-1726. Sydney: Allen and Unwin.

Rudolph, Lloyd. I. and Susanne Hoeber Rudolph. 2010. Federalism as State Formation in India: A Theory of Shared and Negotiated Sovereignty. International Political Science Review 31(5): 
$553-571$.

Ruggie, John Gerard. 1983. Continuity and Transformation in the World Polity: Toward a Neorealist Synthesis. World Politics35 (2): 261-285.

Ruggie, John Gerard. 1998. Constructing the World Polity: Essays on International Institutionalization. London: Routledge.

Siddiqi, Majid. 2005. The British Historical Context and Petitioning in India. New Delhi: Aakar Books.

Spruyt, Hendrik. 1994. The Sovereign State and its Competitors: An Analysis of Systems Change. Princeton: Princeton University Press.

Steensgaard, Niels. 1973. The Asian Trade Revolution of the Seventeenth Century: The East India Companies and the Decline of the Caravan Trade. Chicago: University of Chicago Press.

Steinberg, Philip J. 1990. The Social Construction of the Ocean. Cambridge: Cambridge University Press.

Stern, Philip A.J. 2008. “A Politie of Civill \& Military Power”: Political Thought and the Late Seventeenth Century Foundations of the East India Company State. Journal of British Studies47(2): 253-283.

Stern, Philip A.J. 2011. The Company-State. Corporate Sovereignty and the Early Modern Foundations of the British Empire in India. Oxford: Oxford University Press.

Strang, David. 1991.Anomaly and Commonplace in European Political Expansion: Realist and Institutionalist Accounts. International Organization 42 (2), 143-162. 
Streusand, Douglas E. 2011.Islamic Gunpowder Empires: Ottomans, Safavids and Mughals. Boulder: Westview.

Subrahmanyam, Sanjay. 2007. Holding the World in Balance: The Connected Histories of the Iberian Overseas Empires 1500-1640.American Historical Review 112 (5): 1359-1385.

Subrahmanyam, Sanjay. 2012. The Portuguese Empire in Asia 1500-1700. Second edition. Chichester: Wiley-Blackwell.

Subrahmanyam, Sanjay and Luis Filipe F.R. Thomas. 1990. Evolution of Empire: The Portuguese in the Indian Ocean during the Sixteenth Century. In The Political Economy of Merchant Empires: State Power and World Trade 1350-1750 edited by James D. Tracy Cambridge: Cambridge University Press, pp. 298-331.

Thomson, Janice E.1994. Mercenaries, Pirates and Sovereign: State-Building and ExtraTerritorial Violence in Early-Modern Europe, Princeton: Princeton University Press.

Tracy, James D. 1990. Introduction. In The Political Economy of Merchant Empires: State Power and World Trade 1350-1750edited byJames D. Tracy.Cambridge: Cambridge University Press, pp.1-21.

Van Goor, J.J. 1985. A Madman in the City of Ghosts: Nicolass Kloek in Pontianak. Itinerario, 9 (2): 196-211.

Waltz, Kenneth N. 1979. Theory of International Politics. Reading, Mass.: Addison-Wesley.

Ward, Kerry. 2008. Networks of Empire: Forced Migration in the Dutch East India Company. Cambridge: Cambridge University Press. 
Weber, Cynthia. 1994.Simulating Sovereignty: Intervention, the State, and Symbolic Exchange. Cambridge: Cambridge University Press.

White, Richard. 1991. The Middle Ground: Indians, Empires and Republics in the Great Lakes Region, 1650-1815. Cambridge: Cambridge University Press.

Wills Jr. J.E. 2000. Was There A Vasco Gama Epoch? Recent Historiography. In Anthony Disney and Emily Booth(Eds.), Vasco da Gama and the Linking of Europe and Asia. Oxford: Oxford University Press.

Wilson, Jon E. 2008. The Domination of Strangers - Modern Governance in Eastern India, 1788-1835. London: Palgrave MacMillan.

Wolters, O.W. 1982.History, Culture and Region in Southeast Asia. Singapore: Southeast Asia Program Publications. 